\title{
30. PROTON-MICROPROBE TRACE ELEMENT STUDY OF SELECTED LEG 135 CORE SAMPLES ${ }^{1}$
}

\author{
A. Ewart ${ }^{2}$ and W.L. Griffin ${ }^{3}$
}

\begin{abstract}
In-situ proton-microprobe analyses are presented for glasses, plagioclases, pyroxenes, olivines, and spinels in eleven samples from Sites 834-836, 839, and 841 (vitrophyric rhyolite), plus a Tongan dacite. Elements analyzed are $\mathrm{Mn}, \mathrm{Ni}, \mathrm{Cu}, \mathrm{Zn}, \mathrm{Ga}, \mathrm{Rb}$, $\mathrm{Sr}, \mathrm{Y}, \mathrm{Zr}, \mathrm{Pb}$, and $\mathrm{Sn}$ (in spinels only). The data are used to calculate two sets of partition coefficients, one set based on the ratio of element in mineral/element in coexisting glass. The second set of coefficients, thought to be more robust, is corrected by application of the Rayleigh fractionation equations, which requires additional use of modal data. Data are presented for phenocryst core-rim phases and microphenocryst-groundmass phases from a few samples.

Comparison with published coefficients reveals an overall consistency with those presented here, but with some notable anomalies. Examples are relatively high $\mathrm{Zr}$ values for pyroxenes and abnormally low $\mathrm{Mn}$ values in olivines and clinopyroxenes from Site 839 lavas. Some anomalies may reflect kinetic effects, but interpretation of the coefficients is complicated, especially in olivines from Sites 836 and 839, by possible crystal-liquid disequilibrium resulting from mixing processes.
\end{abstract}

\section{INTRODUCTION}

The primary aim of this contribution is to provide a set of partition coefficients for plagioclase, pyroxenes, olivines, and spinels, determined on 11 samples selected from the Ocean Drilling Program (ODP) Leg 135 cores. Such partition coefficients are an essential part of the data base required for the petrogenetic modeling of such processes as fractional crystallization and melting. Surprisingly, the available published data are very erratic in their availability. Partition coefficients for the rare-earth elements (REE), Mn, $\mathrm{Cu}, \mathrm{Ni}, \mathrm{Co}, \mathrm{Sc}$, $\mathrm{Cr}, \mathrm{V}, \mathrm{Sr}, \mathrm{Ba}$, and $\mathrm{Ga}$ have been determined for plagioclases, pyroxenes, and magnetites from various basaltic andesites, andesites and dacites from the modern axial Tongan volcanoes (Ewart et al., 1973; Ewart and Hawkesworth, 1987). These coefficients are based on analyses, by spark source mass spectrography, optical spectrography, and X-ray fluorescence methods, of mineral separates. Although by far the majority of natural partition coefficients are determined on physically separated minerals (and coexisting glass), usually from volcanic rocks, inherent problems include the difficulty of attaining high purity separates (an essential requirement) and the particularly difficult problem of small mineral inclusions, especially phases such as apatite. The very low $\mathrm{P}_{2} \mathrm{O}_{5}$ and $\mathrm{Zr}$ concentrations of the Tongan mafic lavas, however, generally precludes the presence of apatite and zircon as inclusions within this volcanic suite. It is clearly advantageous to apply an in-situ technique for trace element analyses of coexisting mineral and glass phases in appropriate volcanic rocks for determining the partitioning behavior of trace elements between minerals, and mineral-glass phases. One such technique is protonmicroprobe analysis, described below.

\section{METHODS}

Proton-microprobe analyses were carried out at the CSIRO Heavy Ion Analytical Facility, using methods described by Griffin et al. $(1988,1989)$. A beam of $3 \mathrm{MeV}$ protons is focused on to a target by an electrostatic lens (Sie and Ryan, 1985), forming a spot approxi-

\footnotetext{
'Hawkins, J., Parson, L., Allan, J., et al., 1994. Proc. ODP, Sci. Results, 135: College Station, TX (Ocean Drilling Program).

Department of Earth Sciences, University of Queensland, St. Lucia, Queensland 4072, Australia.

${ }^{3}$ Division of Exploration Geoscience, CSIRO, North Ryde, New South Wales, 2113 , Australia.
}

mately $20 \mu \mathrm{m}$ in diameter. The X-radiation produced is collected by a $\mathrm{Si}(\mathrm{Li})$ detector, and the data processed as described by Ryan et al. (1990). During the analyses reported here, the major element spectra were attenuated by a $200-\mu \mathrm{m}$ filter to allow use of higher beam currents $(6-12 \mathrm{nA})$ and the attainment of relatively low detection levels within analysis times of approximately $5-10 \mathrm{~min}$. Such a filter, however, limits analyzed elements to those with $\mathrm{Z}>\mathrm{Fe}$. Where possible, at least three spots were analyzed per mineral, and the spectra of individual spots summed to produce a composite spectrum and therefore enhance counting statistics. Quoted uncertainties are 1 standard deviation (SD), based on the counting statistics. The analytical methods employed are in principle independent of standards (Ryan et al., 1990). However, analytical data are normalized to electron microprobe analyses for $\mathrm{Fe}$ to correct for bias caused by possible accumulated charge measurement problems; these corrections are usually within $10 \%-15 \%$, except where beam penetration has occurred through a mineral. The accuracy of the technique is estimated to be on the order of $5 \%$ relative, at concentration levels greater than 2-3 times mean detection levels (Ryan et al., 1990).

Electron microprobe analyses were carried out at the University of Queensland, Centre for Microscopy and Microanalysis using a newly installed, fully automatic JEOL superprobe. Glass analyses used an enlarged beam of approximately $15 \mu \mathrm{m}$ diameter.

\section{SAMPLES AND PROCEDURES}

Eleven Leg 135 samples were chosen, based on a range of whole rock compositions, relatively abundant phenocrysts, and the presence of preserved interstitial glass. Seven of the samples are olivine \pm clinopyroxene \pm plagioclase basalts, three are clinopyroxeneorthopyroxene-plagioclase basaltic andesites, and one is a vitrophyric low- $\mathrm{K}_{2} \mathrm{O}$ rhyolite from Site 841 . The additional sample is a twopyroxene-plagioclase dacite from Fonualei Island, Tonga (Sample F32/69; see Ewart et al., 1973, for details). Modal analyses and details of the site and core locations are presented in Table 1.

Calculated partition coefficients (= D) are presented for the elements $\mathrm{Mn}, \mathrm{Ni}, \mathrm{Cu}, \mathrm{Zn}, \mathrm{Ga}, \mathrm{Rb}, \mathrm{Sr}, \mathrm{Y}, \mathrm{Zr}, \mathrm{Ba}$, and $\mathrm{Pb}$ (Tables 2-6). Additional elements that are capable of routine analysis by proton microprobe include $\mathrm{Ge}, \mathrm{Nb}, \mathrm{Mo}$, Th, U, La Ce, Nd, As, Sb, Br, Hf, and $\mathrm{Sn}$. The very depleted geochemistry of the Lau-Tonga magmas (e.g., see Ewart et al., this volume), however, precluded the routine detection of these elements in the constituent minerals within the lavas, although $\mathrm{Sn}$ was detected in the spinels. The analytical data for 
glasses and minerals are presented in Tables 7-11, whereas electron microprobe analyses of the glasses are presented in Table 12. All glasses analyzed were found to be homogeneous.

Partition coefficients are calculated in two ways. The simplest, and most commonly used, is the ratio of the concentration of element in mineral/concentration of element in coexisting glass (= liquid; apparent partition coefficients). Korringa and Noble (1971) pointed out, however, that most phenocryst minerals are zoned both with respect to major and trace elements, and as only the surfaces of such zoned crystals are likely to be in equilibrium with the surrounding liquid during crystallization, the simple bulk crystal/liquid ratio calculation will thus potentially yield erroneous coefficients. The extent of this error will depend on the percentage of each phenocryst, the percentages of coprecipitating phenocrysts, and how close ideal fractional crystallization was approached. To minimize the error, Korringa and Noble (1971) applied and adapted the Rayleigh distillation equations to calculate partition coefficients. The necessary data required are (1) concentration of each element in groundmass glass; (2) weight fractions of the groundmass and the phenocryst phases (determined from modes; Table 1); and (3) the average concentrations of elements in each of the various phenocryst phases. In principle, the coefficients can be calculated from some combination of groundmass, wholerock, and phenocryst trace element data (eqs. 3-5 in Korringa and Noble, 1971). In this report, only groundmass and phenocryst data are used (thus using eqs. 5, 7, and 8 of Korringa and Noble, 1971). The results of this method of calculation are shown in Tables 2-6, where they can be compared with the simpler ratio method of calculation. Ewart et al. (1973) showed that for the Tongan volcanic rocks, in which partition coefficients were based on analyses of separated mineral concentrations, the Rayleigh corrected data resulted in more robust coefficients. This is especially important for element-mineral combinations with high partition coefficients, such as $\mathrm{Ni}$ in olivine. Nevertheless, implicit in these calculations is the assumption that throughout phenocryst precipitation, the phenocryst phases maintained the same relative proportions in which they are now observed in each rock. The proximity of most of the samples to the relevant cotectic curves (e.g., Ewart et al., this volume) suggests that this assumption probably is reasonable. The Rayleigh correction procedure is also considered to provide a more realistic upper limit for those partition coefficients based on element abundances that are below their detection limits. Therefore, these are shown in Tables 2-6 where appropriate. In these tables, the 1 standard deviation (SD) of uncertainty given for the Rayleigh calculated coefficients are based on the \pm 1 SD errors given for each element analyzed (Tables 7-11), with coefficients calculated for the \pm extremes of values; these yield values that are equivalent to the method used by Green et al. (1989).

The relatively large spot size of the proton-microprobe beam (approximately $20 \mu \mathrm{m}$ in diameter) precluded detailed study of zoning within phenocryst and microphenocryst phases, ideally required to test the applicability of the Rayleigh correction procedure. Nevertheless, in a number of samples, phenocryst/microphenocryst cores and rims (or associated groundmass phases) were analyzed. Comparison of the data for these pairs, together with comparisons of the numerically higher partition coefficients calculated by both calculation methods, suggest that the Rayleigh corrected data provide increased consistency, and thus provide more reliable coefficients. For most of the numerically smaller partition coefficients, however, differences between the two sets of coefficients are relatively insignificant.

In Tables 2-6, comparisons of the new data are made with previous data (Rayleigh corrected) for basaltic andesites, andesites, and dacites for Tonga (Ewart et al., 1973), and also with data from a partition coefficient data base, created from published partition coefficients determined for naturally occurring phenocryst-groundmass data from volcanic rocks. The data set includes some 900 sets of mineral-liquid pairs, with about 4000 individual coefficients. Examples of its application are given in Ewart et al. (1988) and Ewart and Chappell (1989).

\section{DISCUSSION}

\section{Plagioclase}

Only $\mathrm{Sr}$ and $\mathrm{Ga}$ are strongly partitioned into plagioclase, for those elements analyzed (Table 2). Apart from anomalously high $\mathrm{Rb}$ and $\mathrm{Ba}$ coefficients in Sample 135-836A-3H-CC, 0-9 cm, and the Sr coefficient in Sample 135-835B-4R-1, 131-141 cm, the determined coefficients are consistent with the range of relevant coefficients determined for the Tongan lavas and the more general basaltic and basaltic andesite coefficients in the literature. $\mathrm{Zr}$, however, exhibits what are effectively bimodal coefficients, lying either between 0.024 and $<0.12$, or between 0.22 and 0.38 . The lower set of values are within the range reported in the literature, but the second set appear anomalous. It is interesting to note, however, that these higher $\mathrm{Zr}$ coefficients all occur in samples from Sites 835 and 839 , those lavas having strongly developed "arclike" affinities (e.g., Ewart et al., this volume), whereas the Fonualei dacite (active Tongan arc) also exhibits a relatively high plagioclase $\mathrm{Zr}$ coefficient $(D=0.36)$. Zircon has not been observed in these samples (noting their rather low $\mathrm{Zr}$ abundances), and thus the presence of small zircon inclusions is precluded as an explanation. Similarly, the possible presence of glass inclusions within the plagioclases (caused, for example, by quench crystallization) is also an unlikely explanation, as if should they enhance the apparent $\mathrm{Zr}$ concentrations in the plagioclases, they would also result in abnormally high coefficients for $\mathrm{Zn}$ and $\mathrm{Cu}$. These were not observed, however. The possibility that the explanation lies in kinetic effects accompanying rapid high-temperature crystallization is feasible, but as yet impossible to evaluate.

The $\mathrm{Sr}$ coefficients are similar to the basaltic plagioclase megacryst value of $1.61 \pm 0.67$ given by Phinney and Morrison (1990), and with two exceptions, within the range of literature values (Table 2). The exceptions are Samples 135-835B-4R-1, 134-141 cm (high Sr) and 135-839B-38R-1, 8-12 cm (low Sr); although the possibility of disequilibrium plagioclase exists in these two examples (e.g., Ewart et al., this volume), this could also apply to other samples in which the $\mathrm{Sr}$ coefficients lie within the normal range. The $\mathrm{Rb}$ coefficients are variable, but consistent with published values, whereas $\mathrm{Ba}$ is below detection levels in most samples. Published Ba partition coefficients are mostly $<1$ (see also Phinney and Morrison, 1990), consistent with the Leg 135 data set, with the exception of two anomalous values, one of which is a quenched plagioclase rim in Sample 135$839 \mathrm{~B}-23 \mathrm{R}-1,0-6 \mathrm{~cm}$. The $\mathrm{Pb}$ coefficients are also variable, but significantly, the higher $\mathrm{D}$ values all have relatively high analytical uncertainties and thus need to be treated with caution. The preferred $D$ values, based on the present data set, are between approximately 0.5 to 0.6 .

The Tongan plagioclase data (Ewart et al., 1973) exhibit increasing partition coefficients from basaltic andesites through to dacites, especially evident for $\mathrm{Sr}$ and $\mathrm{Ga}$. Such trends are not so clearly defined in the present data set, although the $\mathrm{Zn}$ coefficients are relatively high in the rhyolitic and dacitic plagioclases, whereas $\mathrm{Ga}$ and $\mathrm{Sr}$ are relatively high in the rhyolitic plagioclase. In two of the samples (135-839B-23R$1,0-6 \mathrm{~cm}$, and $-35 \mathrm{R}-1,7-11 \mathrm{~cm}$ ), comparative core and rim compositions are available. The only two elements that exhibit systematic and significant differences are $\mathrm{Sr}$ and $\mathrm{Ga}$, the partition coefficients decreasing at the plagioclase rims of both samples. For other elements, differences are within analytical uncertainties.

\section{Clinopyroxene}

This phase is notable for relatively strong partitioning of $\mathrm{Mn}, \mathrm{Ni}$, $\mathrm{Cu}, \mathrm{Zn}, \mathrm{Ga}, \mathrm{Y}$, and, in some samples, even $\mathrm{Sr}$ into its lattice. The coefficients, with the notable exception of $\mathrm{Sr}$, are within the ranges of published values for basaltic and basaltic andesite clinopyroxenes, although few data for $\mathrm{Y}$ and $\mathrm{Ga}$ are available for natural clinopyroxenes. Experimental data of Green et al. (1989) and Kuehner et al. 
(1989) indicate basaltic clinopyroxene DY values of 0.1 and $0.3-0.53$, respectively, compared with values of $0.58-0.89$ in this study. The Mn coefficients for the mafic lavas are slightly lower than determined in the Tonga lavas (although the $\mathrm{D}_{\mathrm{Mn}}$ value for the Fonualei dacite is similar), but are mostly comparable to the lower range reported in the literature (including the experimental data of Dunn, 1987), with the values in the samples from Site 839 being noticeably lower than those in the clinopyroxenes from Sites 834 and 835 . The Ni coefficients are puzzlingly variable, although the Rayleigh corrected data are more coherent; it is suggested that the variability is most likely to reflect the relative stages of clinopyroxene and olivine precipitation, and their effects on the $\mathrm{Ni}-\mathrm{MgO}$ contents of the coexisting liquid.

The $\mathrm{Sr}$ coefficients are mostly higher than normally reported, with $\mathrm{D}_{\mathrm{Sr}}$ of 0.13 being the upper limit (see also experimental data of Green et al. [1989] and Kuehner et al. [1989]). The $\mathrm{Zr}$ coefficients tend to be bimodal, either low $(<0.09)$ or between 0.13 and 0.31 . Published values on natural clinopyroxenes are also erratic (undoubtedly reflecting included zircon in some cases), whereas experimentally determined values range from 0.1 (Green et al., 1989) to 0.27-0.44 (Kuehner et al., 1989) to 0.05-0.45 (Dunn and McCallum, 1982). The latter authors attribute the observed variability of their $\mathrm{Zr}$ data to $\mathrm{Al}$ in the pyroxenes and melt.

A trend toward increasing partition coefficients is apparent for $\mathrm{Mn}$ (most strongly developed in the rhyolite), $\mathrm{Zn}$, and $\mathrm{Y}$ (in the rhyolite). For Sample 135-839B-23R-1, 0-6 cm, comparative analyses are presented for microphenocrystal and groundmass clinopyroxene. The results indicate significant increased partitioning of $\mathrm{Mn}, \mathrm{Ni}, \mathrm{Cu}, \mathrm{Zn}$, and $\mathrm{Sr}$ in the groundmass phase, which at least in part may be kinetically controlled.

\section{Orthopyroxene}

Data are available only from Site 839 basaltic andesites (Unit 9) and the Fonualei dacite. The strong partitioning of $\mathrm{Mn}$ and especially $\mathrm{Ni}$ are evident. Although the partition coefficients (Table 4) are generally consistent with the very limited published values for natural orthopyroxenes, data are scarce for $\mathrm{Zr}, \mathrm{Ga}, \mathrm{Rb}, \mathrm{Sr}, \mathrm{Y}, \mathrm{Zr}, \mathrm{Ba}$, and $\mathrm{Pb}$. The experimental data of Green et al. (1989) give partition coefficients for $\mathrm{Sr}, \mathrm{Zr}$, and $\mathrm{Y}$ of $0.04,0.18$, and 0.18 , respectively. The measured Leg 135 data are higher for $\mathrm{Sr}$ and $\mathrm{Y}$, ranging from 0.07 to $0.19(\mathrm{Sr})$, and from 0.19 to $0.32(\mathrm{Y})$. Measured $\mathrm{Zr}$ coefficients are variable, ranging between $<0.03$ and 0.14 (with a single groundmass value of 0.59 )

The $\mathrm{Zn}$ and $\mathrm{Mn}$ coefficients increase markedly in the dacitic orthopyroxene, consistent with transition element behavior in the Tongan pyroxenes in general (Ewart et al., 1973). Comparative coefficients are presented for microphenocrystal and groundmass orthopyroxene in Sample 135-839B-29R-1, 134-136 cm. Significant increases in the coefficients of $\mathrm{Cu}, \mathrm{Zn}, \mathrm{Ga}$, and $\mathrm{Zr}$, and a decrease in $\mathrm{Y}$, occur in the groundmass phase.

\section{Olivine}

The elements $\mathrm{Mn}, \mathrm{Ni}$, and $\mathrm{Zn}$ exhibit the strongest partitioning (predictably) into olivine. Coefficients for Mn range from 1.18 to 1.81 for samples from Sites 834 and 835 (similar to the experimental values determined by Dunn [1987]), but are notably lower in samples from Sites 836 and $839(0.83-0.96)$. Coefficients for $\mathrm{Ni}$ and $\mathrm{Zn}$ (in part) behave similarly, suggesting olivine-liquid disequilibrium in the lavas from Sites 836 and 839. Hart and Davis (1978) found that olivine $\mathrm{Ni}_{\mathrm{i}} /$ liquid $_{\mathrm{Ni}}(=\mathrm{D})$ partitioning is strongly correlated with melt $\mathrm{MgO}$, but it is independent of liquid $\mathrm{Ni}$ concentrations, with only weak temperature dependence. These authors expressed the compositional dependence as $\mathrm{D}=(124 / \mathrm{MgO})-0.9$. Predicted $\mathrm{MgO}$ (liquid) values, using this equation with the Rayleigh corrected coefficients, are shown in Table 5, and are compared with $\mathrm{MgO}$ abundances in coexisting glasses and the whole rocks. The predicted $\mathrm{MgO}$ values are consis- tently low in the basalts from Sites $834-836$, indicating that the $\mathrm{Ni}$-partition coefficients are higher than are predicted by the equation. Magma mixing within the Site 834-836 magmas is a possible explanation, as discussed elsewhere in this volume (Hergt and Nilsson; Bryan et al.), although $\mathrm{Mg}-\mathrm{Fe}$ partitioning data suggest only minimal effects in the Site 834 samples analyzed here (Ewart et al., this volume). In the case of the two Site 839 samples, the predicted $\mathrm{MgO}$ (liquid) values are actually higher than observed. In these examples, incorporation of highly magnesian olivines into more evolved melt is indicated by additional Mg-Fe crystal-liquid exchange data (Allan, this volume; Ewart et al., this volume).

Notwithstanding the evidence pointing toward disequilibrium olivine in many of the Leg 135 samples, the calculated partition coefficients are within the ranges reported in the literature for basalts and basaltic andesites, with the exception of two anomalously high $\mathrm{Pb}$ values, and the relatively high $\mathrm{Zr}$ coefficients in the two Site 839 olivines, noted above. Comparative core and rim compositions are available for Sample 135-834B-35R-1, 58-60 cm. These indicate significant decreases in the coefficients for $\mathrm{Mn}$ and $\mathrm{Ni}$, and increases in $\mathrm{Zn}$ and $\mathrm{Sr}$, in the slightly more Fe-rich rim zones.

\section{Spinels}

The Cr-spinels exhibit strong partitioning of $\mathrm{Mn}, \mathrm{Ni}, \mathrm{Zn}$, and $\mathrm{Ga}$, and $\mathrm{Sn}$ is detected in two analyses. Comparison of core and rim compositions from Sample 135-839B-22R-1, 6-9 cm, show that the $\mathrm{Zn}$ coefficient changes significantly, decreasing in the rim zone, which is thought to be temperature controlled.

Two titaniferous magnetites have been analyzed: (1) from the Site 841 vitrophyric rhyolite and (2) from the Fonualei dacite. Again, Mn, $\mathrm{Zn}$, and $\mathrm{Ga}$ are strongly partitioned into the spinel, with the coefficients increasing markedly in the rhyolitic magnetite; this latter phase also shows high $\mathrm{D}_{\mathrm{Y}}$. Few magnetite data are available for comparison from equivalent dacites and low- $\mathrm{K}_{2} \mathrm{O}$ rhyolites. Recent data of Francalanci (1989) for magnetite in a potassic andesite, however, are relevant, in that they report partition coefficients for $\mathrm{Sr}, \mathrm{Zr}$, and $\mathrm{Y}$ of $0.15,0.45$, and 1.7 , respectively. These are very similar to the values determined in this work.

\section{SUMMARY}

Based on in-situ proton-microprobe analyses of phenocrystal, microphenocrystal, and some groundmass mineral phases and coexisting glasses, partition coefficients are presented for $\mathrm{Mn}, \mathrm{Ni}, \mathrm{Cu}, \mathrm{Zn}, \mathrm{Ga}, \mathrm{Rb}$, $\mathrm{Sr}, \mathrm{Y}, \mathrm{Zr}, \mathrm{Ba}$, and $\mathrm{Pb}$. Mineral phases include plagioclase, clinopyroxenes, orthopyroxene, olivine, $\mathrm{Cr}$-spinel, and titaniferous magnetite. Eleven samples have been analyzed from Leg 135 drill sites comprising basalts from Sites 834-836 and 839; basaltic andesites from Site 839 ; and low- $\mathrm{K}_{2} \mathrm{O}$ rhyolite from Site 841 . An additional dacite from Fonualei Island (modern Tongan Arc) is included. Data for additional elements were not obtained because of the generally depleted trace element geochemistry of the Lau Basin and Tongan lavas.

The partition coefficients are presented first as ratios of element concentration in mineral/concentration of element in glass (apparent partition coefficients), and second as coefficients corrected using the Rayleigh distillation model (also requiring modal data). We consider that the Rayleigh corrected data provide a more robust data set, especially for the larger partition coefficients.

Comparison with published partition coefficients, including a set determined specifically on modern Tongan lavas, reveals an overall consistency with the data determined in this work, but with some notable anomalies. Examples are some relatively high- $\mathrm{Zr}$ coefficients in plagioclases, relatively high-Sr coefficients in pyroxenes, and low-Mn coefficients in clinopyroxenes and olivines from Site 839 lavas. We suggest that some of the anomalies could be kinetically controlled, this receiving some support from comparisons of limited data for phenocryst core-rim and microphenocryst-groundmass pairs 
from the same samples. Interpretation of the overall partition coefficient data is, however, complicated by possible crystal-liquid disequilibrium resulting from mixing processes, thought to show most obviously in the olivines from lavas of Sites 836 and 839. Calculated coefficients for some elements increase markedly in the dacite and rhyolite (relative to mineral phases in the mafic lavas). Examples are $\mathrm{Zr}, \mathrm{Ga}$, and $\mathrm{Sr}$ in plagioclase; $\mathrm{Mn}, \mathrm{Ga}$, and $\mathrm{Y}$ in clinopyroxene; $\mathrm{Mn}$ and $\mathrm{Zn}$ in orthopyroxene; and $\mathrm{Zn}, \mathrm{Ga}$, and $\mathrm{Y}$ in the rhyolite titaniferous magnetite.

\section{ACKNOWLEDGMENTS}

Special thanks are owed to Tin Tin Win of the CSIRO, HIAF Laboratory for invaluable help with data processing, and to Dr. C.J. Stephens (University of Queensland) for much help in processing electron microprobe data. Reviews by T.H. Green and R.C. Price greatly improved the manuscript presentation.

\section{REFERENCES*}

Dunn, T., 1987. Partitioning of $\mathrm{Hf}, \mathrm{Lu}, \mathrm{Ti}$, and Mn between olivine, clinopyroxene and basaltic liquid. Contrib. Mineral. Petrol., 96:476-484.

Dunn, T., and McCallum, I.S., 1982. The partitioning of $\mathrm{Zr}$ and $\mathrm{Nb}$ between diopside and melts in the system diopside-albite-anorthite. Geochim. Cosmochim. Acta, 46:623-629.

Ewart, A., Bryan, W.B., and Gill, J., 1973. Mineralogy and geochemistry of the younger volcanic islands of Tonga, southwest Pacific. J. Petrol., 14:429-465.

Ewart, A., and Chappell, B.W., 1989. East Australian petrology and geochemistry: trace element geochemistry. In Johnson R.W. (Ed.), Intraplate Volcanism in Eastern Australia and New Zealand: Cambridge (Cambridge Univ. Press), 219-235.

Ewart, A., Chappell, B.W., and Menzies, M.A., 1988. An overview of the geochemical and isotopic characteristics of the eastern Australia Cainozoic volcanic provinces. In Menzies, M.A. (Ed.), Oceanic and Continental Lithosphere: Similarities and Differences. J. Petrol., Spec. Publ., 225-274.

Ewart, A., and Hawkesworth, C.J., 1987. The Pleistocene-Recent Tonga-Kermadec arc lavas: interpretation of new isotopic and rare earth data in terms of a depleted mantle source model. J. Petrol., 28:495-530.
Francalanci, L., 1989. Trace element partition coefficients for minerals in shoshonitic and calc-alkaline rocks from Stromboli Island (Aeolian Arc). Neues Jahrb. Mineral. Abh., 160:229-247.

Green, T.H., Sie, S.H., Ryan, C.G., and Cousens, D.R., 1989. Proton microprobe-determined partitioning of $\mathrm{Nb}, \mathrm{Ta}, \mathrm{Zr}, \mathrm{Sr}$ and $\mathrm{Y}$ between garnet, clinopyroxene and basaltic magmas at high pressure and temperature. Chem. Geol., 74:201-216.

Griffin, W.L., Jaques, A.L., Sie, S.H., Ryan, C.G., Cousens, D.R., and Suter, G.F., 1988. Conditions of diamond growth: a proton microprobe study of inclusions in West Australian diamonds. Contrib. Mineral. Petrol., 99:143-152.

Griffin, W.L., Smith, D., Boyd, F.R., Cousens, D.R., Ryan, C.G., Sie, S.H., and Suter, G.F., 1989. Trace element zoning in garnets from sheared mantle xenoliths. Geochim. Cosmochim. Acta, 53:561-567.

Hart, S.R., and Davis, K.E., 1978. Nickel partitioning between olivine and silicate melt. Earth Planet. Sci. Lett., 40:203-219.

Korringa, M.K., and Noble, D.C., 1971. Distribution of $\mathrm{Sr}$ and Ba between natural feldspar and igneous melt. Earth Planet. Sci. Lett., 11:147-151.

Kuehner, S.M., Laughlin, J.R., Grossman, L., Johnson, M.L., and Burnett, D.C., 1989. Determination of trace element mineral/liquid partition coefficients in melilite and diopside by ion and electron microprobe techniques. Geochim. Cosmochim. Acta, 53:3115-3130.

Phinney, W.C., and Morrison, D.A., 1990. Partition coefficients for calcic plagioclase: implications for Archean anorthosites. Geochim. Cosmochim. Acta, 54:1639-1654.

Ryan, C.G., Cousens, D.R., Sie, S.H., Griffin, W.L., and Clayton, E.J., 1990. Quantitative PIXE microanalysis in the geosciences. Nucl. Instrum. Methods Phys. Res., Sect. B, 47:55-71.

Sie, S.H., and Ryan, C.G., 1985. An electrostatic "Russian" quadruplet microprobe lens. Nucl. Instrum. Methods, Phys. Res., Sect. B, 15:664-670.

\footnotetext{
Abbreviations for names of organizations and publication titles in ODP reference lists follow the style given in Chemical Abstracts Service Source Index (published by American Chemical Society).
}

Date of initial receipt: 29 June 1992

Date of acceptance: 3 April 1993

Ms 135SR-146

Table 1. Modal analyses (volume percent) of samples analyzed by proton microprobe.

\begin{tabular}{|c|c|c|c|c|c|c|c|c|c|c|c|c|}
\hline Hole & $834 \mathrm{~B}$ & $834 \mathrm{~B}$ & $835 B$ & $836 \mathrm{~A}$ & $836 \mathrm{~A}$ & $839 \mathrm{~B}$ & $839 \mathrm{~B}$ & $839 \mathrm{~B}$ & $839 \mathrm{~B}$ & $839 \mathrm{~B}$ & & $841 B$ \\
\hline Core, section & $35 R-1$ & $57 \mathrm{R}-1$ & $4 \mathrm{R}-1$ & $3 \mathrm{H}-\mathrm{CC}$ & $4 \mathrm{H}-\mathrm{CC}$ & $22 R-1$ & $23 R-1$ & $29 \mathrm{R}-1$ & $35 R-1$ & $38 \mathrm{R}-1$ & & SOR-1 \\
\hline Interval (cm) & $58-60$ & $126-128$ & $134-141$ & & $0-13$ & $6-9$ & $0-6$ & $134-136$ & $7-11$ & $8-12$ & & s-9 \\
\hline Unit & 8 & 13 & 1 & 3 & 3 & 3 & 3 & 9 & 9 & 9 & & $2 \mathrm{~B}$ \\
\hline \multicolumn{13}{|l|}{ Phenocrysts } \\
\hline Plagjoclase & 8.0 & 9.0 & 10.7 & 8.1 & 13.7 & - & - & 11.5 & 14.8 & 9.3 & Plagioclase & 14.1 \\
\hline Clinopyroxene & 5.0 & 2.8 & 6.9 & - & - & 1.2 & 1.1 & 0.2 & 0.1 & 0.4 & Quartz & 6.8 \\
\hline Olivine & 1.5 & 0.9 & 1.7 & 2.4 & 3.5 & 16.8 & 16.2 & - & - & - & Clinopyroxene & 1.1 \\
\hline Orthopyroxene & - & - & - & - & - & - & - & 0.5 & 0.7 & 0.3 & Orthopyroxene & 0.5 \\
\hline Chromite & - & - & - & - & $<\ll 0.1$ & 0.3 & 0.2 & - & - & - & Magnetite & 0.8 \\
\hline \multirow[t]{2}{*}{ Total Phenocrysts } & 14.5 & 12.7 & 19.3 & 10.5 & 17.2 & 18.3 & 17.5 & 12.2 & 15.5 & 10.0 & Hornblende & $\infty .1$ \\
\hline & & & & & & & & & & & Total & 23.3 \\
\hline \multirow[t]{2}{*}{ Vesicles } & 18.0 & 15.7 & 4.7 & 1.2 & - & 31.1 & 34.1 & 15.9 & 17.7 & 4.8 & & \\
\hline & & & & & & & & & & & Vesicles & 8.7 \\
\hline \multicolumn{2}{|l|}{ Groundmass } & & & & & & & & & & $\begin{array}{l}\text { Groundmass } \\
\text { (glass) }\end{array}$ & 76.7 \\
\hline Plagioclase & 2.2 & 1.5 & 1.0 & 1.8 & - & - & $\infty 0.1$ & 21.6 & 11.5 & 12.5 & $N$ & 1799 \\
\hline Clinopyroxene & 0.2 & 0.5 & 0.5 & - & - & 10.3 & 19.6 & 14.2 & - & 2.9 & $*$ & \\
\hline Olivine & 0.1 & - & 0.1 & - & - & 1.7 & 0.8 & - & - & - & & \\
\hline Opaques & - & - & - & - & - & - & - & 0.8 & - & - & & \\
\hline Mesostasis (glass) & - & - & - & - & 82.8 & - & - & $\$ 1.1$ & 17.0 & - & & \\
\hline Mesostasis (composite) & 82.9 & 85.3 & 79.0 & 87.7 & - & 56.2 & 57.8 & - & 53.2 & 71.0 & & \\
\hline Segregation vesicle glass & - & - & - & - & - & 2.2 & 1.2 & - & 2.8 & 3.6 & & \\
\hline \multicolumn{2}{|c|}{ Segregation vesicle infilling (devitrified) } & - & - & - & - & - & 11.3 & 3.0 & - & - & & \\
\hline$N$ & 1447 & 1613 & 1360 & 1205 & 1721 & 1827 & 2066 & 1214 & 1332 & 2315 & & \\
\hline
\end{tabular}

Notes: Data are recalculated vesicle-free. $N=$ number of points counted.

Includes devitrified \pm glassy mesostasis. 
Table 2. Calculated partition coefficients for plagioclase phases analyzed by proton microprobe.

\begin{tabular}{|c|c|c|c|c|c|c|c|}
\hline \multirow{4}{*}{$\begin{array}{l}\text { Hole } \\
\text { Core, section } \\
\text { Interval }(\mathrm{cm}) \\
\text { Type }\end{array}$} & $834 \mathrm{~B}$ & $834 \mathrm{~B}$ & $835 \mathrm{~B}$ & $836 \mathrm{~A}$ & $836 \mathrm{~A}$ & 839B & $839 \mathrm{~B}$ \\
\hline & $35 \mathrm{R}-1$ & $57 \mathrm{R}-1$ & $4 R-1$ & $3 \mathrm{H}-\mathrm{CC}$ & $4 \mathrm{H}-\mathrm{CC}$ & 23R-1 & 23R-1 \\
\hline & $58-60$ & $126-128$ & $134-141$ & $0-9$ & $0-13$ & $0-6$ & $0-6$ \\
\hline & Phen & Phen & Phen & Phen & Phen & Mphen core & Mphen rim \\
\hline $\mathrm{Mn}(1)$ & . & - & - & - & $\cdot$ & . & - \\
\hline (2) & $<0.035$ & $<0.048$ & $<0.068$ & $<0.083$ & $<0.029$ & $<0.068$ & $<0.074$ \\
\hline $\mathrm{Ni}$ (1) & - & - & - & - & - & - & - \\
\hline (2) & $<0.15$ & $<0.26$ & $<0.22$ & $<0.23$ & $<0.36$ & $<0.73$ & $<0.73$ \\
\hline $\mathrm{Cu}$ (1) & 0.11 & 0.15 & - & $\cdot$ & 0.045 & 0.072 & 0.084 \\
\hline (2) & $0.13(0.01)$ & $0.17(0.01)$ & $<0.064$ & $<0.11$ & $0.049(0.004)$ & $0082(0.022)$ & $0.095(0.015)$ \\
\hline $\mathrm{Zn}$ (1) & 0.070 & 0.13 & 0.028 & 0.20 & 0.042 & 0.095 & 0.091 \\
\hline (2) & $0.075(0.01)$ & $0.14(0.01)$ & $0.031(0.015)$ & $0.21(0.02)$ & $0.045(0.006)$ & $0.096(0.014)$ & $0.092(0.014)$ \\
\hline $\mathrm{Ga}$ (1) & 1.26 & 1.18 & 1.84 & 0.99 & 0.96 & 1.74 & 1.46 \\
\hline (2) & $1.28(0.10)$ & $1.18(0.01)$ & $1.83(0.03)$ & $1.00(0.08)$ & $0.98(0.04)$ & $1.94(0.02)$ & $1.64(0.03)$ \\
\hline $\mathrm{Rb}$ (1) & - & - & 0.37 & 3.2 & - & - & - \\
\hline (2) & $<0.75$ & $<0.21$ & $0.41(0.10)$ & $2.9(0.07)$ & $<0.78$ & $<0.49$ & $<0.58$ \\
\hline Sr (1) & 1.53 & 1.45 & 4.11 & 1.57 & 1.01 & 1.68 & 1.49 \\
\hline (2) & $1.53(0.01)$ & $1.43(0.01)$ & $3.63(0.02)$ & $1.55(0.01)$ & $1.03(0.01)$ & $1.92(0.02)$ & $1.69(0.03)$ \\
\hline (1) & - & - & . & . & 0.084 & - & - \\
\hline (2) & $<0.076$ & $<0.12$ & $<0.19$ & $<0.12$ & $0.092(0.026)$ & $<0.29$ & $<0.31$ \\
\hline $\mathrm{Zr} \quad$ (1) & 0.024 & 0.022 & 0.34 & - & $-\quad$ a & - & 0.22 \\
\hline (2) & $0.026(0.020)$ & $0.024(0.023)$ & $0.38(0.04)$ & $<0.13$ & $<0.029$ & $<0.12$ & $0.24(0.12)$ \\
\hline $\mathrm{Ba}$ & - & - & - & 5.24 & - & - & 2.0 \\
\hline (2) & $<0.84$ & $<0.92$ & $<1.15$ & $4.39(1.0)$ & $<0.86$ & $<1.87$ & $2.2(0.3)$ \\
\hline $\mathrm{Pb} \quad$ (1) & 3.5 & 0.59 & - & 2.10 & 0.96 & $\cdot$ & $\cdot$ \\
\hline (2) & $2.95(0.86)$ & $0.61(0.04)$ & $<0.51$ & $2.00(0.43)$ & $0.98(0.22)$ & $<1.21$ & $<1.3$ \\
\hline An\%(mol.) & $75-77$ & $78-83$ & $71-86$ & $76-86$ & $80-90$ & $85-88$ & $84-85$ \\
\hline
\end{tabular}

Table 2 (continued).

\begin{tabular}{|c|c|c|c|c|c|c|c|c|c|}
\hline $\begin{array}{l}\text { Hole } \\
\text { Core, section } \\
\text { Interval }(\mathrm{cm}) \\
\text { Type } \\
\end{array}$ & $\begin{array}{l}839 \mathrm{~B} \\
29 \mathrm{R}-1 \\
134-136 \\
\text { Phen }\end{array}$ & $\begin{array}{l}839 \mathrm{~B} \\
35 \mathrm{R}-1 \\
7-11 \\
\text { Phen core }\end{array}$ & $\begin{array}{l}839 \mathrm{~B} \\
35 \mathrm{R}-1 \\
7-11 \\
\text { Phen rim }\end{array}$ & $\begin{array}{l}839 \mathrm{~B} \\
38 \mathrm{R}-1 \\
8-12 \\
\text { Phen }\end{array}$ & $\begin{array}{l}841 \mathrm{~B} \\
50 \mathrm{R}-1 \\
5-9 \\
\text { Phen }\end{array}$ & $\begin{array}{l}\text { Fonualei } \\
\text { F32/69 } \\
\text { Phen }\end{array}$ & $\begin{array}{l}\text { Tonga } \\
\text { basaltic } \\
\text { andesites }\end{array}$ & $\begin{array}{l}\text { Tonga }{ }^{*} \\
\text { andesites } \\
\text { and dacites }\end{array}$ & $\begin{array}{l}\text { Literature + } \\
\text { basalts and } \\
\text { basaltic } \\
\text { andesites }\end{array}$ \\
\hline Mn (1) & $\cdot$ & $\cdot$ & - & 0.032 & - & 0.047 & & & $0.016-0.07$ \\
\hline (2) & $<0.029$ & $<0.045$ & $<0.046$ & $0.030(0.007)$ & $<0.079$ & $0.045(0.004)$ & & & \\
\hline $\mathrm{Ni} \quad(1)$ & $\cdot$ & - & - & - & . & - & & & $0.05-0.22$ \\
\hline (2) & $<0.44$ & $<0.94$ & $<0.94$ & $<0.51$ & $<0.63$ & $<0.52$ & & & \\
\hline \multirow{2}{*}{$\begin{array}{ll}\mathrm{Cu} & \text { (1) } \\
& \text { (2) }\end{array}$} & 0.054 & - & - & 0.028 & - & 0.23 & & & $0.004-0.7$ \\
\hline & $0.073(0.01)$ & $<0.075$ & $<0.075$ & $0.033(0.004)$ & $<0.60$ & $0.24(0.02)$ & $0.07-0.24$ & $0.08-0.32$ & \\
\hline \multirow{2}{*}{$\begin{array}{r}\mathrm{Zn} \text { (1) } \\
\text { (2) }\end{array}$} & 0.043 & 0.058 & 0.072 & 0.037 & 0.18 & 0.141 & & & 0.04-0.19 \\
\hline & $0055(0.01)$ & $0.067(0.023)$ & $0.084(0.015)$ & $0.043(0.006)$ & $0.15(0.01)$ & $0.142(0.01)$ & & & \\
\hline Ga (1) & 1.43 & 1.73 & 1.36 & 1.30 & 1.59 & 1.03 & & & \\
\hline (2) & $1.37(0.07)$ & $1.57(0.01)$ & $1.30(0.01)$ & $1.26(0.07)$ & $1.54(0.04)$ & $1.03(0.01)$ & $0.88-1.1$ & $1.1-1.7$ & \\
\hline $\mathrm{Rb} \quad$ (1) & - & 0.27 & 0.36 & - & - & 0.25 & & & $0.026-0.36$ \\
\hline (2) & $<0.11$ & $0.30(0.08)$ & $0.40(0.08)$ & $<0.11$ & $<0.087$ & $0.25(0.01)$ & & & \\
\hline Sr (1) & 2.27 & 1.48 & 1.35 & 0.93 & 4.06 & 1.37 & & & $1.04-2.22$ \\
\hline (2) & $1.90(0.02)$ & $1.39(0.01)$ & $1.30(0.01)$ & $0.94(0.01)$ & $3.44(0.05)$ & $1.37(0.01)$ & $1.4-1.7$ & $1.8-2.6$ & \\
\hline (1) & . & - & - & - $\quad$ a & - & - & & & $0.05-0.13$ \\
\hline (2) & $<0.10$ & $<0.24$ & $<0.28$ & $<0.073$ & $<0.023$ & $<0.072$ & & & \\
\hline $\mathrm{Zr}$ & 0.17 & 0.24 & 0.20 & - & . & 0.36 & & & $0.01-0.05$ \\
\hline (2) & $0.24(0.02)$ & $0.28(0.01)$ & $0.22(0.05)$ & $<0.030$ & $<0.008$ & $0.36(0.01)$ & & & \\
\hline \multirow[t]{2}{*}{$\mathrm{Ba}$} & 0.39 & . & - & - & 0.28 & 0.29 & & & $0.054-1.05$ \\
\hline & $0.48(0.08)$ & $<0.71$ & $<0.73$ & $<0.45$ & $0.32(0.04)$ & $0.29(0.04)$ & $0.15-0.19$ & $0.11-0.17$ & \\
\hline \multirow{2}{*}{$\begin{array}{ll}\mathrm{Pb} \quad(1) \\
\quad(2) \\
\end{array}$} & 1.15 & - & - & 0.48 & . & - & & & $0.1-5.4$ \\
\hline & $1.13(0.26)$ & $<0.64$ & $<0.70$ & $0.51(0.02)$ & $<0.74$ & $<0.60$ & & & \\
\hline An\%(mol.) & $82-89$ & $88-91$ & $74-83$ & 87.95 & $40-48$ & 88.9 & & & \\
\hline
\end{tabular}

Notes: $(1)=$ calculated as $\mathrm{C}_{\text {solid }} / \mathrm{Cliquid}_{\text {, and }}(2)$ calculated assuming Rayleigh fractionation. Phen $=$ phenocrysts, and Mphen $=$ microphenocrysts. Figures in parentheses are $1 \mathrm{SD}$ based on the 1 SD proton-microprobe uncertainties.

*After Ewart et al. (1973) based on mineral separates.

${ }^{+}$See text. 
Table 3. Calculated partition coefficients for clinopyroxene phases analyzed by proton microprobe.

\begin{tabular}{|c|c|c|c|c|c|c|c|c|c|c|c|}
\hline $\begin{array}{l}\text { Hole } \\
\text { Core, section } \\
\text { Interval }(\mathrm{cm}) \\
\text { Type }\end{array}$ & $\begin{array}{l}834 \mathrm{~B} \\
35 \mathrm{R}-1 \\
58-60 \\
\text { Mphen }\end{array}$ & $\begin{array}{l}834 \mathrm{~B} \\
57 \mathrm{R}-1 \\
126-128 \\
\text { Mphen } \\
\end{array}$ & $\begin{array}{l}835 B \\
4 R-1 \\
134-141 \\
\text { Phen }\end{array}$ & $\begin{array}{l}839 \mathrm{~B} \\
23 \mathrm{R}-1 \\
0-6 \\
\text { Mphen }\end{array}$ & $\begin{array}{l}839 \mathrm{~B} \\
23 \mathrm{R}-1 \\
0-6 \\
\text { Gmss }\end{array}$ & $\begin{array}{l}839 \mathrm{~B} \\
38 \mathrm{R}-1 \\
8-12 \\
\text { Phen }\end{array}$ & $\begin{array}{l}841 \mathrm{~B} \\
50 \mathrm{R}-1 \\
5-9 \\
\text { Phen }\end{array}$ & $\begin{array}{l}\text { Fonualei } \\
\text { F32/69 } \\
\text { Phen }\end{array}$ & $\begin{array}{l}\text { Tonga* } \\
\text { basaltic } \\
\text { andesites }\end{array}$ & $\begin{array}{l}\text { Tonga }{ }^{*} \\
\text { andesites } \\
\text { and dacites }\end{array}$ & $\begin{array}{l}\text { Literature+ } \\
\text { basalts and } \\
\text { basaltic } \\
\text { andesites }\end{array}$ \\
\hline $\operatorname{Mn}(1)$ & 0.89 & 0.70 & 0.95 & 0.55 & 0.61 & 0.68 & 14.4 & 2.25 & & & $0.81-1.5$ \\
\hline (2) & $0.90(0.01)$ & $0.69(0.01)$ & $0.99(0.02)$ & $0.56(0.02)$ & $0.62(0.02)$ & $0.65(0.02)$ & $12.1(0.2)$ & $2.16(0.01)$ & $1.2-1.5$ & $1.8-4.2$ & \\
\hline $\mathrm{Ni}$ (1) & 4.60 & 0.44 & 5.82 & 1.85 & 4.67 & - & - & - & & & $0.26-8.4$ \\
\hline (2) & $2.82(0.13)$ & $0.40(0.04)$ & $3.70(0.12)$ & $0.26(0.01)$ & $0.66(0.01)$ & $<0.51$ & $<2.5$ & $<2.1$ & $5.6-8.4$ & & \\
\hline $\mathrm{Cu}$ (1) & 0.52 & 0.55 & & 0.28 & 0.60 & 0.51 & - & - & & & $0.07-0.7$ \\
\hline (2) & $0.57(0.02)$ & $0.59(0.01)$ & $<0.056$ & $0.31(0.02)$ & $0.67(0.02)$ & $0.59(0.01)$ & $<1.94$ & $<0.27$ & $0.12-0.69$ & $0.25-0.87$ & \\
\hline $\mathrm{Zn}(1)$ & 0.43 & 0.77 & 0.27 & 0.53 & 0.71 & 0.58 & 2.63 & 1.08 & & & $0.33-0.74$ \\
\hline (2) & $0.46(0.01)$ & $0.81(0.02)$ & $0.29(0.01)$ & $0.53(0.01)$ & $0.72(0.01)$ & $0.67(0.01)$ & $2.06(0.02)$ & $1.09(0.01)$ & & & \\
\hline $\mathrm{Ga}(1)$ & 0.55 & 0.56 & 0.30 & 0.35 & 0.40 & 1.15 & - & 0.28 & & & 0.35 \\
\hline (2) & $0.56(0.03)$ & $0.56(0.02)$ & $0.30(0.02)$ & $0.39(0.03)$ & $0.44(0.08)$ & $1.11(0.01)$ & $<0.29$ & $0.28(0.01)$ & & & \\
\hline $\mathrm{Rb}(1)$ & - & - & - & - & - & 0.30 & - & - & & & $0.001-0.08$ \\
\hline (2) & $<0.64$ & $<0.21$ & $<0.15$ & $<0.39$ & $<0.41$ & $0.34(0.07)$ & $<0.21$ & $<0.12$ & & & \\
\hline Sr (1) & 0.44 & 0.52 & 0.070 & 0.43 & 0.60 & 0.83 & 0.10 & 0.10 & & & $0.07-0.13$ \\
\hline (2) & $0.44(0.01)$ & $0.52(0.01)$ & $0.062(0.01)$ & $0.49(0.01)$ & $0.68(0.01)$ & $0.85(0.01)$ & $0.086(0.014)$ & $0.10(0.01)$ & & & \\
\hline $\mathbf{Y}(1)$ & 0.68 & 0.54 & 0.62 & 0.79 & 0.69 & 0.56 & 1.92 & 0.76 & & & 0.42 \\
\hline (2) & $0.73(0.02)$ & $0.58(0.01)$ & $0.68(0.02)$ & $0.89(0.05)$ & $0.78(0.08)$ & $0.64(0.08)$ & $2.14(0.01)$ & $0.79(0.03)$ & & & \\
\hline $\mathrm{Zr}$ (1) & 0.23 & - & 0.12 & . & . & . & 0.076 & 0.30 & & & $0.14-1.24$ \\
\hline (2) & $0.25(0.01)$ & $<0.025$ & $0.13(0.01)$ & $<0.081$ & $<0.086$ & $<0.049$ & $0.088(0.011)$ & $0.31(0.03)$ & & & \\
\hline $\mathrm{Ba}(1)$ & - & - & . & - & - & - & - & 0.15 & & & $0.001-0.05$ \\
\hline (2) & $<0.56$ & $<0.74$ & $<0.55$ & $<1.15$ & $<1.25$ & $<0.69$ & $<0.22$ & $0.16(0.06)$ & & & \\
\hline $\mathrm{Pb}(1)$ & - & 0.65 & . & - & . & 1.34 & - & - & & & $0.15-1.0$ \\
\hline (2) & $<0.71$ & $0.67(0.02)$ & $<0.40$ & $<1.0$ & $<1.1$ & $1.42(0.70)$ & $<2.1$ & $<1.7$ & & & \\
\hline $\mathrm{Ca}$ (atomic.\%) & 39.8 & 41.8 & 41.5 & 42.3 & 42.3 & 39.6 & 39.7 & 36.6 & & & \\
\hline $\mathrm{Mg}$ & 51.5 & 493 & 48.8 & 49.0 & 47.5 & 47.6 & 33.2 & 37.8 & & & \\
\hline $\mathrm{Fe}+\mathrm{Mn}$ & 8.8 & 9.0 & 9.8 & 8.7 & 10.3 & 12.8 & 27.2 & 25.6 & & & \\
\hline
\end{tabular}

Notes: $(1)=$ calculated as $\mathrm{C}_{\text {solid }} / \mathrm{Cliquid}_{\text {, and }}(2)$ calculated assuming Rayleigh fractionation. $\mathrm{Mphen}=$ microphenocrysts, Gmss $=$ groundmass, and Phen $=$ phenocrysts. Figures in parentheses are 1 SD based on the 1 SD proton-microprobe uncertainties.

* After Ewart et al. (1973) based on mineral separates.

${ }^{+}$See text.

Table 4. Calculated partition coefficients for orthopyroxene phases analyzed by proton microprobe.

\begin{tabular}{|c|c|c|c|c|c|c|c|c|}
\hline $\begin{array}{l}\text { Hole } \\
\text { Core, section } \\
\text { Interval }(\mathrm{cm}) \\
\text { Type }\end{array}$ & $\begin{array}{l}839 \mathrm{~B} \\
29 \mathrm{R}-1 \\
134-136 \\
\text { Mphen }\end{array}$ & $\begin{array}{l}839 \mathrm{~B} \\
29 \mathrm{R}-1 \\
134-136 \\
\text { Gmss }\end{array}$ & $\begin{array}{l}839 \mathrm{~B} \\
35 \mathrm{R}-1 \\
7-11 \\
\text { Phen }\end{array}$ & $\begin{array}{l}839 \mathrm{~B} \\
38 \mathrm{R}-1 \\
8-12 \\
\text { Phen }\end{array}$ & $\begin{array}{l}\text { Fonualei } \\
\text { F32/69 } \\
\text { Phen }\end{array}$ & $\begin{array}{l}\text { Tonga* } \\
\text { basaltic } \\
\text { andesites }\end{array}$ & $\begin{array}{l}\text { Tonga* } \\
\text { andesites- } \\
\text { dactes }\end{array}$ & $\begin{array}{l}\text { Literature }^{+} \\
\text {basaltic } \\
\text { andesites }\end{array}$ \\
\hline Mn (1) & 1.55 & 1.49 & 2.28 & 2.01 & 3.0 & & & $1.8-2.2$ \\
\hline (2) & $1.85(0.30)$ & $1.80(0.25)$ & $1.36(0.02)$ & $1.92(0.17)$ & $2.88(0.05)$ & $1.8-2.2$ & $2.4-6.4$ & \\
\hline $\mathrm{Ni}$ (1) & 8.22 & 7.67 & 15.2 & 21.4 & - & & & $5.2-14.8$ \\
\hline (2) & $6.85(0.15)$ & $6.53(0.27)$ & $16.2(0.1)$ & $22.7(0.4)$ & - & $7.3-11.0$ & - & \\
\hline $\mathrm{Cu}(1)$ & 0.15 & 0.53 & 0.10 & 0.11 & - & & & $0.16-0.92$ \\
\hline (2) & $0.21(0.01)$ & $0.69(0.02)$ & $0.12(0.01)$ & $0.12(0.06)$ & $<0.12$ & $0.17-0.92$ & $0.34-1.2$ & \\
\hline $\operatorname{Zn}(1)$ & 0.90 & 1.0 & 1.01 & 1.10 & 1.67 & & & - \\
\hline (2) & $1.16(0.05)$ & $1.28(0.05)$ & $1.18(0.02)$ & $1.27(0.01)$ & $1.68(0.02)$ & & & \\
\hline $\mathrm{Ga}(1)$ & 0.20 & 0.38 & 0.25 & 0.25 & 0.27 & & & . \\
\hline (2) & $0.20(0.02)$ & $0.36(0.04)$ & $0.23(0.02)$ & $0.24(0.04)$ & $0.27(0.03)$ & & & \\
\hline $\mathrm{Rb}(1)$ & - & - & - & - & - & & & 0.029 \\
\hline (2) & $<0.08$ & $<0.2$ & $<0.09$ & $<0.12$ & $<0.08$ & & & \\
\hline Sr (1) & 0.23 & 0.22 & 0.074 & 0.11 & 0.079 & & & 0.01 \\
\hline (2) & $0.19(0.01)$ & $0.18(0.07)$ & $0.069(0.003)$ & $0.12(0.01)$ & $0.079(0.006)$ & & & \\
\hline Y (1) & 0.24 & 0.14 & 0.23 & 0.22 & 0.24 & & & . \\
\hline (2) & $0.32(0.02)$ & $0.19(0.05)$ & $0.26(0.02)$ & $0.25(0.02)$ & $0.24(0.02)$ & & & \\
\hline $\mathrm{Zr}(1)$ & - & 0.44 & 0.12 & 0.076 & 0.20 & & & - \\
\hline (2) & $<0.03$ & $0.59(0.01)$ & $0.14(0.02)$ & $0.089(0.013)$ & $0.21(0.01)$ & & & \\
\hline $\mathrm{Ba}(1)$ & - & - & - & - & 0.17 & & & 0.01 \\
\hline (2) & $<0.17$ & $<0.34$ & $<0.18$ & $<0.28$ & $0.17(0.03)$ & & & \\
\hline $\mathrm{Pb}(1)$ & - & - & 0.43 & . & - & & & - \\
\hline (2) & $<0.45$ & $<0.45$ & $0.46(0.09)$ & $<0.46$ & $<1.0$ & & & \\
\hline $\mathrm{Ca}$ (atomic \%) & 3.9 & 4.7 & 4.2 & 4.2 & 4.4 & & & \\
\hline $\mathrm{Mg}$ & 72.8 & 68.2 & 73.7 & 73.0 & 53.3 & & & \\
\hline $\mathrm{Fe}+\mathrm{Mn}$ & 23.2 & 27.1 & 22.2 & 22.8 & 42.3 & & & \\
\hline
\end{tabular}

Notes: $(1)=$ calculated as $\mathrm{C}_{\text {solid }} / \mathrm{Cliquid}_{\text {, and }}(2)$ calculated assuming Rayleigh fractionation. Mphen = microphenocrysts, Gmss $=$ groundmass, and Phen = phenocrysts. Figures in parentheses are 1 SD based on the 1 SD proton-microprobe uncertainties.

* After Ewart et al. (1973) based on mineral separates.

+ See text. 
Table 5. Calculated partition coefficients for olivine phases analyzed by proton microprobe.

\begin{tabular}{|c|c|c|c|c|c|c|c|c|c|}
\hline Hole & $834 \mathrm{~B}$ & $834 \mathrm{~B}$ & $834 \mathrm{~B}$ & $835 \mathrm{~B}$ & $836 \mathrm{~A}$ & $836 \mathrm{~A}$ & $839 \mathrm{~B}$ & $839 \mathrm{~B}$ & Literature $^{+}$ \\
\hline Core, section & $35 \mathrm{R}-1$ & $35 R-1$ & $57 R-1$ & $4 \mathrm{R}-1$ & $3 \mathrm{H}-\mathrm{CC}$ & $4 \mathrm{H}-\mathrm{CC}$ & $22 \mathrm{R}-1$ & $23 \mathrm{R}-1$ & basalts- \\
\hline Interval $(\mathrm{cm})$ & $58-60$ & $58-60$ & $126-128$ & $134-141$ & $0-6$ & $0-13$ & $6-9$ & $0-6$ & basaltic \\
\hline Type & Phen core & Phen rim & Phen & Phen & Phen & Phen & Phen & Phen & andesites \\
\hline $\operatorname{Mn}(1)$ & 1.36 & 1.19 & 1.82 & 1.15 & 1.0 & 0.91 & 0.83 & 0.79 & $0.8-2.6$ \\
\hline (2) & $1.38(0.03)$ & $1.21(0.01)$ & $1.81(0.06)$ & $1.18(0.01)$ & $0.96(0.01)$ & $0.88(0.10)$ & $0.83(0.02)$ & $0.80(0.08)$ & \\
\hline $\mathrm{Ni}(1)$ & 62.6 & 45.3 & 30.0 & 40.7 & 23.3 & 25.3 & 131 & 94.9 & $4.5-21.7$ \\
\hline (2) & $38.4(2.0)$ & $30.6(1.6)$ & $27.0(2.5)$ & $25.9(1.3)$ & $18.0(0.8)$ & $17.4(0.5)$ & $13.8(1.1)$ & $13.5(0.5)$ & \\
\hline $\mathrm{Cu}$ (1) & - & - & 0.54 & - & 0.29 & - & 0.079 & 0.059 & $0.02-4.3$ \\
\hline (2) & $<0.12$ & $<0.13$ & $0.57(0.01)$ & $<0.06$ & $0.31(0.05)$ & $<0.07$ & $0.090(0.01)$ & $0.066(0.017)$ & \\
\hline $\mathrm{Zn}(1)$ & 1.11 & 1.18 & 1.22 & 0.96 & 0.77 & 1.04 & 0.86 & 0.85 & $0.67-3.0$ \\
\hline (2) & $1.19(0.01)$ & $1.27(0.02)$ & $1.29(0.02)$ & $1.07(0.02)$ & $0.80(0.01)$ & $1.12(0.02)$ & $0.87(0.012)$ & $0.86(0.01)$ & \\
\hline Ga (1) & - & - & - & - & - & - & - & - & $0.04-0.05$ \\
\hline (2) & $<0.34$ & $<0.35$ & $<0.42$ & $<0.22$ & $<0.61$ & $<0.41$ & $<0.17$ & $<0.23$ & \\
\hline $\mathrm{Rb}$ (1) & 1.63 & $\cdot$ & - & $\cdot$ & $\cdot$ & 2.1 & 0.77 & - & $0.0002-0.19$ \\
\hline (2) & $1.69(0.7)$ & $<1.7$ & $<0.20$ & $<0.17$ & $<0.33$ & $2.1(0.9)$ & $0.80(0.01)$ & $<0.26$ & \\
\hline Sr (1) & 0.023 & 0.083 & 0.26 & - & - & - & - & 0.011 & $0.002-0.12$ \\
\hline (2) & $0.023(0.02)$ & $0.083(0.01)$ & $0.26(0.02)$ & $<0.014$ & $<0.035$ & $<0.020$ & $<0.009$ & $0.012(0.005)$ & \\
\hline Y (1) & - $\quad x^{2}$ & - & 0.73 & - & - & - & $\cdot$ & & - \\
\hline (2) & $<0.14$ & $<0.15$ & $0.78(0.01)$ & $<0.12$ & $<0.17$ & $<0.11$ & $<0.13$ & & \\
\hline $\mathrm{Zr}(1)$ & 0.11 & 0.062 & - & 0.11 & - & 0.11 & 0.38 & 0.18 & 0.04 \\
\hline (2) & $0.13(0.05)$ & $0.068(0.033)$ & $<0.041$ & $0.12(0.02)$ & $<0.068$ & $0.12(0.04)$ & $0.42(0.09)$ & $0.20(0.03)$ & \\
\hline $\mathrm{Pb}(1)$ & - & - & - & 0.60 & - & - & 0.79 & - & - \\
\hline (2) & $<1.7$ & $<1.7$ & $<0.41$ & $0.64(0.06)$ & $<0.67$ & $<0.15$ & $0.81(0.09)$ & $<0.68$ & \\
\hline Fo (mol\%) & $84-87$ & 83.85 & $83-86$ & $81-85$ & $86-87$ & $87-88$ & $88-92$ & $88-92$ & \\
\hline $\mathrm{MgO}$ predicted liquid & 3.16 & 3.94 & 4.44 & 4.63 & 6.56 & 6.78 & 8.44 & 8.61 & \\
\hline $\mathrm{MgO}$ glass & 6.12 & 6.12 & 6.43 & 6.37 & 8.26 & 8.17 & 6.89 & 6.94 & \\
\hline $\mathrm{MgO}$ whole rock & 7.02 & 7.02 & 7.24 & 7.66 & . & 9.09 & - & 14.83 & \\
\hline
\end{tabular}

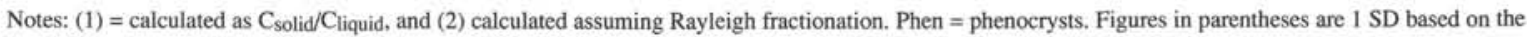
1 SD proton-microprobe uncertainties.

${ }^{+}$See text.

Table 6. Calculated partition coefficients for oxide phases analyzed by proton microprobe.

\begin{tabular}{|c|c|c|c|c|c|c|c|}
\hline \multicolumn{4}{|l|}{ Chromites } & \multicolumn{4}{|l|}{ Magnetites } \\
\hline Hole & $839 \mathrm{~B}$ & $839 \mathrm{~B}$ & $839 \mathrm{~B}$ & $841 B$ & Fonualei & Tonga* & Literature $^{+}$ \\
\hline Core, section & $22 \mathrm{R}-1$ & 23R-1 & 23R-1 & 50R-1 & F32/69 & andesites- & basaltic \\
\hline Interval $(\mathrm{cm})$ & $6-9$ & $0-6$ & $0-6$ & $5-9$ & & dacites & andesites, \\
\hline Type & Mphen & Mphen (cores) & Mphen (rims) & Mphen & Mphen & & andesites \\
\hline $\operatorname{Mn}(1)$ & 6.72 & 5.28 & 4.77 & 14.8 & 2.18 & & $1.4-3.2$ \\
\hline (2) & $6.80(1.25)$ & $5.39(0.88)$ & $4.87(1.20)$ & $12.4(0.4)$ & $2.09(0.29)$ & $1.4-2.9$ & \\
\hline $\mathrm{Ni}$ (1) & 75.4 & 62.1 & 53.8 & & & & $4-19$ \\
\hline (2) & $7.96(0.59)$ & $8.80(0.23)$ & $7.63(1.47)$ & $<2.1$ & - & 19 & \\
\hline $\mathrm{Cu}(1)$ & 0.086 & 0.060 & & & & & $1.3-6.7$ \\
\hline (2) & $0.098(0.017)$ & $0.068(0.025)$ & $<0.15$ & $<3.0$ & . & $1.3-2.3$ & \\
\hline $\mathrm{Zn}(1)$ & 4.91 & 3.90 & 4.78 & 45.7 & 6.23 & & $5.4-12.7$ \\
\hline 2) & $4.96(0.16)$ & $3.96(0.09)$ & $4.85(0.12)$ & $35.9(0.2)$ & $6.27(0.09)$ & & \\
\hline $\mathrm{Ga}(1)$ & 2.06 & 2.28 & 2.64 & 4.49 & 2.90 & & - \\
\hline 2) & $2.34(0.40)$ & $2.56(0.14)$ & $2.96(0.14)$ & $4.37(0.06)$ & $2.90(0.28)$ & & \\
\hline Rb (1) & & & & & & & - \\
\hline (2) & $<1.1$ & $<0.42$ & $<0.79$ & $<0.12$ & . & & \\
\hline Sr (1) & & & & 0.81 & 0.21 & & - \\
\hline (2) & $<0.020$ & $<0.018$ & $<0.033$ & $0.69(0.05)$ & $0.21(0.03)$ & & \\
\hline Y (1) & & & & 1.69 & - & & - \\
\hline (2) & $<0.24$ & $<0.19$ & $<0.36$ & $1.88(0.05)$ & - & & \\
\hline $\mathrm{Zr}$ (1) & & & & 0.27 & 0.39 & & \\
\hline (2) & $<0.21$ & $<0.075$ & $<0.14$ & $0.32(0.02)$ & $0.40(0.05)$ & & \\
\hline $\mathrm{Pb}$ (1) & & & & & & & . \\
\hline (2) & $<1.4$ & $<1.1$ & $<2.3$ & $<2.4$ & . & & \\
\hline
\end{tabular}

Notes: (1) = calculated as $\mathrm{C}_{\text {solid }} / \mathrm{C}_{\text {liquid, and }}$ (2) calculated assuming Rayleigh fractionation. Mphen =microphenocrysts. Figures in parentheses are 1 SD based on the 1 SD proton-microprobe uncertainties.

"After Ewart et al. (1973) based on mineral separates.

${ }^{+}$See text. 
Table 7. Proton-microprobe analyses of Lau-Tonga glasses.

\begin{tabular}{|c|c|c|c|c|c|c|c|c|c|c|c|c|c|c|c|}
\hline Hole & $834 \mathrm{~B}$ & $834 \mathrm{~B}$ & 835B & $836 \mathrm{~A}$ & $836 \mathrm{~A}$ & $839 \mathrm{~B}$ & $839 \mathrm{~B}$ & $839 \mathrm{~B}$ & $839 \mathrm{~B}$ & $839 \mathrm{~B}$ & $839 \mathrm{~B}$ & $839 \mathrm{~B}$ & $839 \mathrm{~B}$ & $841 B$ & Fonualei $32 / 69$ \\
\hline Core, section & $35 R-1$ & $57 R-1$ & $4 R-1$ & $3 \mathrm{H}-\mathrm{CC}$ & $4 \mathrm{H}-\mathrm{CC}$ & $22 \mathrm{R}-1$ & $22 R-1$ & $22 R-1$ & $23 R-1$ & $29 \mathrm{R}-1$ & $35 R-1$ & $35 R-1$ & $38 \mathrm{R}-1$ & $S O R-1$ & \\
\hline Interval $(\mathrm{cm})$ & $58-60$ & $126-128$ & $134-141$ & $0-7$ & $0-13$ & $6-9$ & $6-9$ & $6-9$ & $0-6$ & $134-136$ & $7-11$ & $7-11$ & $8-12$ & $5-9$ & \\
\hline Glass type & Rind & Rind & $\begin{array}{l}\text { Inter- } \\
\text { stitial }\end{array}$ & Gmss & Gmss & Rind ${ }^{*} A^{*}$ & Rind ${ }^{*} B^{*}$ & $\begin{array}{l}\text { Segreg- } \\
\text { ation } \\
\text { vesicle } \\
\text { glass }\end{array}$ & Rind & $\begin{array}{l}\text { Inter- } \\
\text { stitial }\end{array}$ & $\begin{array}{l}\text { Inter- } \\
\text { stitial }\end{array}$ & $\begin{array}{l}\text { Segreg- } \\
\text { ation } \\
\text { vesicle } \\
\text { glass }\end{array}$ & $\begin{array}{l}\text { Inter- } \\
\text { stitial }\end{array}$ & Gmss & Gmss \\
\hline \multicolumn{16}{|c|}{ Trace elements (ppm): } \\
\hline Mn & $944 \pm 63$ & $933=55$ & $978 \div 79$ & $947 \div 70$ & $875 \div 36$ & $855 \pm 47$ & $870 \pm 32$ & $945 \pm 65$ & $1090 \pm 56$ & $1580 \pm 317$ & $1100 \pm 47$ & $1070 \pm 57$ & $1140 \pm 76$ & $293 \pm 23$ & $1740 \pm 49$ \\
\hline $\mathrm{Fe}(\%)$ & $6.54 \pm 0.04$ & $6.75 \pm 0.05$ & $7.27 \pm 0.06$ & $6.41 \pm 0.04$ & $6.56 \div 0.03$ & $6.34=0.04$ & $6.34=0.04$ & $6.85 \pm 0.04$ & $6.16=0.03$ & $10.7 \pm 1.7$ & $8.15 \pm 0.06$ & $8.74=0.07$ & $9.05 \pm 0.06$ & $1.66 \pm 0.007$ & $6.1 \pm 0.04$ \\
\hline $\mathrm{Ni}$ & $17.4 \pm 1.8$ & $20.5 \pm 2.5$ & $22.5 \pm 2.0$ & $46 \pm 3.6$ & $57 \pm 2.9$ & $15.1 \pm 2.3$ & $21.5 \pm 2.1$ & $<6.1$ & $19.5 \pm 2.4$ & $<9$ & $<11$ & $<8$ & $<$ & $s$ & $<5.8$ \\
\hline $\mathrm{Cu}$ & $63=2.0$ & $76 \pm 3.5$ & $89 \geq 4.1$ & $79 \geq 2$ & $110 \pm 2.8$ & $96 \pm 1.6$ & $99 \pm 2.1$ & $134 \pm 2.5$ & $109 \pm 3.1$ & $156=13$ & $124 \pm 4.2$ & $98 \pm 3$ & $177 \pm 4.4$ & $<3.5$ & $26.7 \pm 1.3$ \\
\hline $\mathrm{Zn}$ & $66=2.4$ & $74.5 \pm 2.6$ & $83 \div 2.6$ & $120=3$ & $55=2.2$ & $65 \pm 2.3$ & $63 \pm 1.9$ & $99=1.7$ & $78 \div 24$ & $121=9$ & $107 \pm 3.5$ & $113 \pm 2$ & $105 \pm 2.3$ & $51 \pm 1.0$ & $124 \pm 1.5$ \\
\hline Ga & $12.1=1.5$ & $12 \neq 1.1$ & $11.5=1.1$ & $9.1=1.1$ & $9.2=0.9$ & $12.4 \pm 1.0$ & $9.8 \geq 1.0$ & $12.9 \pm 0.6$ & $10.6=0.7$ & $13.2 \pm 1.4$ & $12.9 \pm 1.1$ & $12.9=0.9$ & $10.9 \pm 1.1$ & $13.8 \pm 0.9$ & $17.7 \pm 0.8$ \\
\hline Ge & $<25$ & $<$ & $<1.8$ & $<2.2$ & $<1.8$ & $<2.8$ & $<2.4$ & $<2.4$ & $<1.9$ & $<3$ & $<3$ & $<2.2$ & $<2.2$ & $<1.6$ & $1.2=0.4$ \\
\hline $\mathrm{Rb}$ & $<1.9$ & $12.1 \pm 1.5$ & $13.2 \pm 1.2$ & $5.5 \geq 1.0$ & $<1.4$ & $<1.8$ & $2.6=0.8$ & $2.5 \approx 0.8$ & $6.8 \pm 0.8$ & $22 \div 2$ & $16.2 \pm 1.8$ & $13.1=1.1$ & $14.3 \pm 1.4$ & $14.7 \pm 0.8$ & $21 \pm 0.9$ \\
\hline Sr & $155 \div 2$ & $163 \div 3$ & $133=2$ & $140=2$ & $148 \pm 2$ & $172 \pm 2.4$ & $169=2.0$ & $204 \div 2.0$ & $168 \pm 1.8$ & $155 \pm 4$ & $209 \pm 5$ & $185 \pm 3$ & $218 \pm 2$ & $53 \pm 1.4$ & $347 \pm 3$ \\
\hline$Y$ & $24=1.2$ & $25 \pm 2$ & $20.6 \pm 1.2$ & $17.1=1.0$ & $19.0 \pm 0.7$ & $13.8=0.8$ & $14.0=0.9$ & $13.9 \pm 0.9$ & $15.2=0.8$ & $26.3 \pm 1.7$ & $19.9 \pm 1.5$ & $22.8 \div 1.2$ & $25 \pm 1.1$ & $64 \pm 1.3$ & $22.9 \pm 1.2$ \\
\hline $\mathrm{z}$ & $79=2.2$ & $134 \pm 5$ & $120 \div 2.8$ & $78 \pm 4$ & $50 \pm 3$ & $11.9=2$ & $19.7 \pm 2.1$ & $18.3 \pm 1.9$ & $40 \div 2.5$ & $75 \pm 5$ & $94: 4$ & $77 \pm 2.5$ & $71 \pm 2.5$ & $202 \div 3$ & $76 \pm 2.4$ \\
\hline $\mathrm{Ba}$ & $68 \div 24$ & $<104$ & $92=30$ & $<68$ & $<7$ & ss & so & $55 \pm 20$ & $66 \pm 20$ & $243 \pm 36$ & $232 \div 48$ & $179 \pm 38$ & $134 \div 28$ & $256 \pm 32$ & $284 \pm 25$ \\
\hline $\mathrm{Pb}$ & $<4.3$ & $15 \div 2.6$ & $12.6 \pm 2.4$ & $10 \div 3$ & $4.5 \pm 1.4$ & $4.3=1.7$ & $4.2 \div 1.9$ & $6.6 \div 1.6$ & $6.0 \pm 1.5$ & $7.4 \pm 3.8$ & $15.1 \geq 2.8$ & $9.2 \pm 2.0$ & $7.1 \neq 3.0$ & $<3.5$ & $<3.7$ \\
\hline $\mathrm{Nb}$ & 3 & $<4.8$ & $<3.7$ & $<3.4$ & $<.3$ & $<3.6$ & $<2.3$ & $<2.6$ & $<2.5$ & 3.8 & $<4.8$ & $<3.3$ & $<3.4$ & $<.7$ & $1.9 \pm 0.53$ \\
\hline Mo & $<3.5$ & $<5$ & $<2.6$ & $<3.3$ & $<2.4$ & $<3.9$ & $<3.5$ & $<3.7$ & - & $<3.8$ & - & $<3.2$ & - & - & - \\
\hline $\mathrm{U}$ & $<3.6$ & $<5.7$ & $<4.5$ & $<4.1$ & $<28$ & $<4.8$ & $<.1$ & $<3.3$ & $<3.2$ & & $<6.0$ & $<4.1$ & $<4.3$ & 2.9 & - \\
\hline$N$ & 3 & 3 & 6 & 5 & 6 & 4 & 5 & 5 & 5 & 3 & 3 & 5 & 6 & 4 & $s$ \\
\hline
\end{tabular}

Notes: Values in ppm except where noted otherwise. Gmss = groundmass. Figures with \pm sign are the 1 SD uncertainties. $N=$ number of discrete spot analyses.

Table 8. Proton-microprobe analyses of Lau-Tonga plagioclase.

\begin{tabular}{|c|c|c|c|c|c|c|c|c|c|c|c|c|c|}
\hline Hole & $834 \mathrm{~B}$ & $834 \mathrm{~B}$ & 835B & $836 \mathrm{~A}$ & $836 \mathrm{~A}$ & $839 \mathrm{~B}$ & $839 \mathrm{~B}$ & $839 \mathrm{~B}$ & $839 \mathrm{~B}$ & $839 \mathrm{~B}$ & $839 \mathrm{~B}$ & $841 \mathrm{~B}$ & Fonualei 32,69 \\
\hline Core, section & $35 R-1$ & $57 R-1$ & $4 R-1$ & $3 \mathrm{H}-\mathrm{CC}$ & $4 \mathrm{H}-\mathrm{CC}$ & $23 \mathrm{R}-1$ & $23 \mathrm{R}-1$ & $29 \mathrm{R}-1$ & $35 R-1$ & $35 R-1$ & $38 R-1$ & SOR-1 & \\
\hline Interval $(\mathrm{cm})$ & 58.60 & $126-128$ & $134-141$ & $0-7$ & $0-13$ & $0-6$ & $0-6$ & $134-136$ & $58-60$ & $58-60$ & $8-12$ & $5-9$ & \\
\hline \multirow[t]{2}{*}{ Type } & Phen & Phen & Phen & Phen & Phen & Mphen & Mphen & Phen & Phen & Phen & Phen & Phen & Phen \\
\hline & Averaged & Averaged & Averaged & Averaged & Averaged & Core & Rim & Averaged & Core & Rim & Averaged & Averaged & Averaged \\
\hline \multicolumn{14}{|c|}{ Trace elements (ppm): } \\
\hline $\mathrm{Mn}$ & $<33$ & $<47$ & $<67$ & $<99$ & $<26$ & $<73$ & $<79$ & $<39$ & $<83$ & $<85$ & $36 \pm 11$ & $<28$ & $82 \pm 10$ \\
\hline $\mathrm{Fe}\left(\%_{0}\right)$ & $0.47 \pm 0.003$ & $0.40 \pm 0.003$ & $0.46 \pm 0.004$ & $0.34=0.005$ & $0.39 \pm 0.002$ & $0.71 \pm 0.005$ & $0.65 \pm 0.005$ & $0.58 \pm 0.004$ & $0.56 \pm 0.005$ & $0.56 \pm 0.003$ & $0.53 \pm 0.003$ & $0.23 \pm 0.01$ & $0.75 \pm 0.004$ \\
\hline $\mathrm{Ni}$ & $<4.3$ & $<6$ & $<8$ & $<14$ & $<3$ & $<10$ & $<10$ & $<5$ & $<11$ & $<11$ & $<4$ & $<$ & 3 \\
\hline $\mathrm{Cu}$ & $6.6=0.7$ & $12.1 \pm 1.2$ & $<5$ & $<8$ & $4.9 \pm 0.5$ & $7.9 \pm 2.3$ & $9.2 \pm 1.7$ & $8.4 \pm 1.0$ & $<8$ & $<8$ & $5 \geq 0.7$ & $<2$ & $6.2 \pm 0.7$ \\
\hline $\mathrm{Zn}$ & $4.6=0.5$ & $9.7 \pm 0.9$ & $2.3 \pm 1.2$ & $23.5 \pm 2.9$ & $2.3 \pm 0.4$ & $7.4 \pm 1.3$ & $7.1 \pm 1.3$ & $5.2 \pm 0.7$ & $6.2 \pm 2.3$ & $7.7 \pm 1.5$ & $3.9=0.6$ & $9.4 \pm 0.6$ & $17.5 \pm 0.6$ \\
\hline Ga & $15.3 \pm 0.6$ & $14.1 \pm 1.4$ & $21.2 * 1.7$ & $9.0 \pm 1.8$ & $8.8 \pm 0.4$ & $18.4 \pm 1.3$ & $15.5 \pm 1.3$ & $18.9 \pm 0.7$ & $22.3 \pm 2.1$ & $17.5 \pm 1.6$ & $14.2 \pm 0.6$ & $21.9 \pm 0.7$ & $18.2 \pm 0.6$ \\
\hline $\mathrm{Ge}$ & $<1.8$ & & $<3$ & $<1.7$ & $<1.8$ & $<3.9$ & $<4.0$ & $<.0$ & $<4.3$ & $<4.7$ & $<2.2$ & $<1.6$ & - \\
\hline $\mathrm{Rb}$ & $<1.4$ & $<2.4$ & $49 \pm 1.6$ & $17.7 \pm 2.7$ & $<1.1$ & 3.0 & 3.6 & $<1.7$ & $4.3 \pm 1.7$ & $5.8 \pm 1.8$ & $<1.4$ & $<1.1$ & $5.2 \pm 0.4$ \\
\hline $\mathrm{St}$ & $237 \div 2$ & $236 \pm 3$ & $547 \pm 5$ & $220 \pm 5$ & $149=1.4$ & $283 \pm 6$ & $250=7$ & $352 \pm 3$ & $310 \pm 5$ & $283 \pm 5$ & $203 \pm 2$ & $215 \pm 2$ & $475 \pm 4$ \\
\hline $\mathrm{Y}$ & $<1.7$ & $<2.8$ & 3.5 & $<1.9$ & 1.650 .5 & $<3.9$ & $<4.2$ & $<2.1$ & $<4.2$ & $<4.9$ & $<1.6$ & $<1.3$ & $1.6 \pm 0.5$ \\
\hline$z$ & $1.9=1.5$ & $2.9 \pm 2.9$ & $41 \pm 4.1$ & - & $<1.3$ & $<4.4$ & $8.7 \pm 4.9$ & $13 \div 2$ & $23 \pm 5.2$ & $18.5 \pm 5$ & $<1.8$ & $<1.4$ & $27 \pm 1.1$ \\
\hline $\mathrm{Ba}$ & $<5$ & 94 & $<103$ & $356 \pm 97$ & $<39$ & $<109$ & $131 \div 52$ & $95 \pm 30$ & $<156$ & $<162$ & $<5$ & $71 \pm 17$ & $81 \pm 18$ \\
\hline $\mathrm{Pb}$ & $3.5 \pm 1.3$ & $8.8 \pm 2.3$ & $<6$ & $21 \pm 5$ & $4.3 \pm 1.1$ & $<7$ & $<7.4$ & $8.5=2.1$ & $\Leftrightarrow$ & $<10$ & $3.4 \pm 1.5$ & $<2.5$ & $<2.2$ \\
\hline$N$ & 4 & 3 & 2 & 2 & 4 & 1 & 1 & 5 & 1 & 1 & 4 & 4 & 6 \\
\hline
\end{tabular}

Notes: Values in ppm except where noted otherwise. Phen $=$ phenocrysts, and Mphen = microphenocrysts. Figures with \pm sign are the 1 SD uncertainties. $N=$ number of discrete spot analyses. 
Table 9. Proton-microprobe analyses of Lau-Tonga pyroxene.

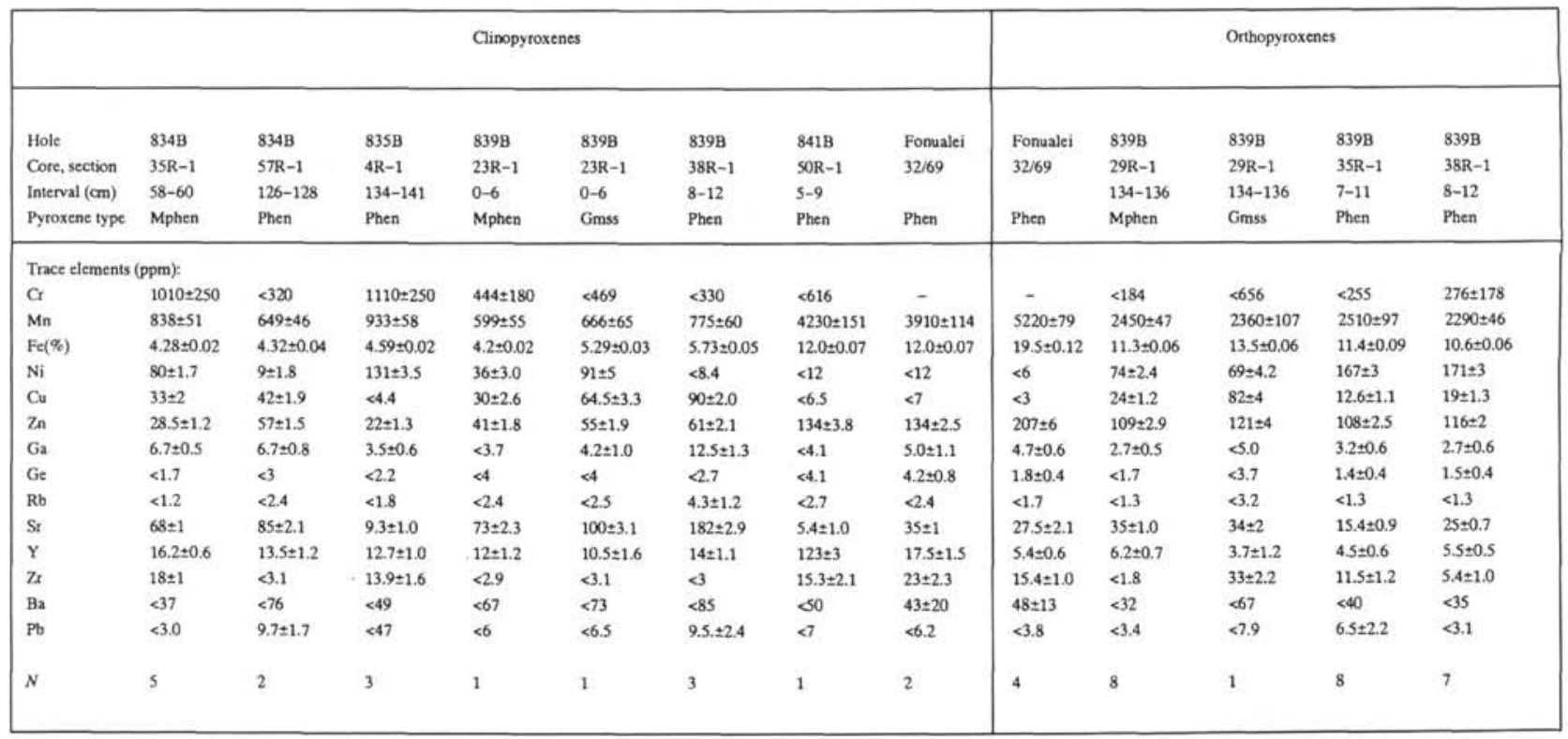

Notes: Values in ppm except where noted otherwise. Mphen = microphenocrysts, Phen = phenocrysts, and Gmss $=$ groundmass. Figures with \pm sign are the 1 SD uncertainties. $N=$ number of discrete spot analyses.

Table 10. Proton-microprobe analyses of Lau-Tonga olivine.

\begin{tabular}{|c|c|c|c|c|c|c|c|c|}
\hline Hole & $834 \mathrm{~B}$ & $834 \mathrm{~B}$ & $834 \mathrm{~B}$ & $835 \mathrm{~B}$ & $836 \mathrm{~B}$ & $836 \mathrm{~A}$ & $839 \mathrm{~B}$ & $839 \mathrm{~B}$ \\
\hline Core, section & $35 \mathrm{R}-1$ & $35 \mathrm{R}-1$ & $S 7 R-1$ & $4 R-1$ & $3 \mathrm{H}-\mathrm{CC}$ & $4 \mathrm{H}-\mathrm{CC}$ & $22 \mathrm{R}-1$ & $23 \mathrm{R}-1$ \\
\hline Interval $(\mathrm{cm})$ & $58-60$ & $58-60$ & $126-128$ & $134-141$ & $0-7$ & $0-13$ & $6-9$ & $0-6$ \\
\hline \multirow[t]{2}{*}{ Type } & Phen & Phen & Phen & Phen & Phen & Phen & Phen & Phen \\
\hline & Core & Rim & Averaged & Averaged & Averaged & & Averaged & Averaged \\
\hline \multicolumn{9}{|c|}{ Trace elements (ppm): } \\
\hline $\mathrm{Mn}$ & $1280 \pm 109$ & $1120 \pm 67$ & $1700=143$ & $1120 \div 83$ & $945 \div 74$ & $793 \div 109$ & $712 \pm 54$ & $857 \div 138$ \\
\hline $\mathrm{Fe}(\%)$ & $10.5=0.05$ & $11.7 \pm 0.05$ & $11.4 \pm 0.07$ & $11.4 \pm 0.06$ & $9.64 \pm 0.05$ & $9.15=0.03$ & $7.66 \pm 0.03$ & $7.11=0.03$ \\
\hline $\mathrm{Ni}$ & $1090 \pm 22$ & $789 \div 21$ & $615 \pm 10$ & $915=11$ & $1070=18$ & $1440 \pm 14$ & $2390 \div 27$ & $1850=18$ \\
\hline $\mathrm{Cu}$ & $<7.8$ & $<7.8$ & $41 \pm 2.6$ & $<4.6$ & $23 \pm 4.3$ & $<7.3$ & $7.7 \pm 1.1$ & $6.4 \pm 1.8$ \\
\hline $2 n$ & $73 \pm 2$ & $78 \pm 4$ & $91 \pm 2$ & $80 \pm 1$ & $92 \div 2$ & $57 \pm 3$ & $55 \pm 1$ & $66 \pm 1.8$ \\
\hline Ga & $<4.1$ & $<4.2$ & $\delta .0$ & 2.5 & s.s & $<3.7$ & $<1.7$ & $<2.2$ \\
\hline $\mathrm{Ge}$ & $<3.4$ & $<3.6$ & $<2.3$ & $<2.0$ & $<.6$ & $<3.2$ & $<1.7$ & $<1.9$ \\
\hline $\mathrm{Rb}$ & $3.1 \pm 1.3$ & $<3.1$ & - & $<2.0$ & - & $3.0 \pm 1.3$ & $2.0 \pm 0.6$ & $<1.6$ \\
\hline $\mathrm{Sr}$ & $3.6 \pm 1.2$ & $12.9=1.6$ & $42 \pm 2$ & $<2.1$ & - & $<2.9$ & $<1.3$ & $1.8 \pm 0.7$ \\
\hline$\gamma$ & $<3.1$ & $<.4$ & $18.3 \pm 1.6$ & $<2.2$ & $<4.9$ & $<3.0$ & $<1.4$ & $<1.8$ \\
\hline $\mathrm{z}$ & $9.0 \pm 3.4$ & $4.9 \pm 2.5$ & - & $13 \pm 3.2$ & - & $5.4 \pm 2.0$ & $6.0<1.1$ & $7.2 \pm 1.5$ \\
\hline $\mathrm{Pb}$ & $<7.2$ & $<7.4$ & - & $7.5: 2.0$ & - & $<6.9$ & $3.4 \pm 2.1$ & 3.9 \\
\hline$N$ & 1 & 1 & 4 & 4 & 3 & 1 & 5 & 3 \\
\hline
\end{tabular}

Notes: Values in ppm except where noted otherwise. Phen = phenocrysts. Figures with \pm sign are the 1 SD uncertainties. $N=$ number of discrete spot analyses. 
Table 11. Proton-microprobe analyses of Lau-Tonga chromite magnetite.

\begin{tabular}{|c|c|c|c|c|c|}
\hline & & \multicolumn{2}{|l|}{ Chromites } & \multicolumn{2}{|l|}{ Magnetites } \\
\hline & & & & & Fonualei \\
\hline Hole & $839 \mathrm{~B}$ & $839 \mathrm{~B}$ & 839 & $841 B$ & $32 / 69$ \\
\hline Core, section & $22 \mathrm{R}-1$ & $23 \mathrm{R}-1$ & $23 \mathrm{R}-1$ & SOR-1 & \\
\hline Interval $(\mathrm{cm})$ & $6-9$ & $0-6$ & $5-9$ & & \\
\hline \multirow[t]{2}{*}{ Type } & Mphen & Mphen & Mphen & Mphen & Mphen \\
\hline & Averaged & Cores & Rim & Averaged & \\
\hline \multicolumn{6}{|c|}{ Trace elements (ppm): } \\
\hline $\operatorname{Mn}(\%)$ & $0.58 \pm 0.14$ & $0.575 \pm 0.13$ & $0.52 \div 0.16$ & $0.433 \pm 0.017$ & $0.38 \div 0.06$ \\
\hline $\mathrm{Fe}(\%)$ & $13.0 \pm 0.03$ & $12.9 \pm 0.02$ & $15.5 \pm 0.04$ & $58.90=0.51$ & $62.3 \pm 0.51$ \\
\hline $\mathrm{Ni}$ & $1380 \pm 20$ & $1210 \pm 20$ & $1050 \pm 23$ & $<10$ & - \\
\hline $\mathrm{Cu}$ & $8.4 \pm 1.7$ & $6.5 \pm 2.6$ & $<14.6$ & $<10$ & - \\
\hline $\mathrm{Zn}$ & $314 \div 4$ & $304 \div 2.5$ & $373 \pm 7$ & $2330 \div 32$ & $772 \pm 23$ \\
\hline $\mathrm{Ga}$ & $22.9 \pm 0.9$ & $24.2 \div 1.0$ & $28 \div 2.2$ & $62 \div 3$ & $51.3 \pm 7.2$ \\
\hline Ge & $<.8$ & 3.0 & $<6.6$ & $<$ & - \\
\hline$R \mathbf{b}$ & $<2.9$ & $<2.6$ & $<4.9$ & $<1.5$ & - \\
\hline St & $<2.9$ & $<.6$ & $<4.9$ & $43 \pm 4$ & $73 \pm 12$ \\
\hline$Y$ & $<2.9$ & $<2.6$ & $<4.9$ & $108 \div 5$ & - \\
\hline$z x$ & $<3.0$ & $<2.7$ & $<5.1$ & $55 \pm 3$ & $30 \pm 4.7$ \\
\hline $\mathrm{Nb}$ & $<3.5$ & $<2.7$ & $<5,4$ & $<4$ & - \\
\hline $\mathrm{Pb}$ & $<5.7$ & $<6.2$ & $<13$ & $<8$ & - \\
\hline Sn & $21 \pm 4$ & $<11$ & $30 \pm 8$ & $30 \pm 4$ & $26 \pm 7.8$ \\
\hline Mo & $<4$ & $<3$ & $<6$ & $<7$ & - \\
\hline As & & & & - & $16.7 \pm 3.5$ \\
\hline$N$ & 4 & 4 & 1 & 3 & 1 \\
\hline
\end{tabular}

Notes: Values in ppm except where noted otherwise. Mphen $=$ microphenocrysts. Figures with \pm sign are the 1 SD uncertainties. $N=$ number of discrete spot analyses.

Table 12. Electron microprobe analyses of glasses analyzed by proton microprobe.

\begin{tabular}{|c|c|c|c|c|c|c|c|c|c|c|c|c|}
\hline Hole & $834 \mathrm{~B}$ & $834 \mathrm{~B}$ & $835 \mathrm{~B}$ & $836 \mathrm{~A}$ & $836 \mathrm{~A}$ & $839 \mathrm{~B}$ & 839B & $839 \mathrm{~B}$ & $839 \mathrm{~B}$ & $839 \mathrm{~B}$ & 839B & $841 B$ \\
\hline Core,section & $35 \mathrm{R}-1$ & $57 \mathrm{R}-1$ & $4 \mathrm{R}-1$ & $3 \mathrm{H}-\mathrm{CC}$ & $4 \mathrm{H}-\mathrm{CC}$ & $22 \mathrm{R}-1$ & $22 \mathrm{R}-1$ & $23 \mathrm{R}-1$ & $35 \mathrm{R}-1$ & $35 \mathrm{R}-1$ & $38 \mathrm{R}-1$ & $50 \mathrm{R}-1$ \\
\hline Interval $(\mathrm{cm})$ & $58-60$ & $126-128$ & $134-141$ & $0-6$ & $0-13$ & $6-9$ & $6-9$ & $0-6$ & $7-11$ & $7-11$ & $8-12$ & $5-9$ \\
\hline Type & Rind & Rind & Interstitial & Gmss & Gmss & Rind & Segregation & Rind & Interstitial & Segregation & Interstitial & Gmss* \\
\hline \multicolumn{13}{|c|}{ Major elements (wt.\%) } \\
\hline $\mathrm{SiO}_{2}$ & 52.82 & 52.07 & 52.69 & 50.46 & 49.87 & 53.18 & 54.48 & 52.83 & 58.00 & 55.92 & 52.35 & 77.44 \\
\hline $\mathrm{TiO}_{2}$ & 1.28 & 1.31 & 1.07 & 0.87 & 0.86 & 0.64 & 0.68 & 0.68 & 1.19 & 1.04 & 0.89 & 0.25 \\
\hline $\mathrm{Al}_{2} \mathrm{O}_{3}$ & 15.61 & 15.66 & 15.23 & 15.26 & 15.16 & 15.55 & 17.08 & 15.21 & 14.14 & 14.18 & 13.79 & 12.19 \\
\hline $\mathrm{FeO}^{*}$ & 8.52 & 8.79 & 9.52 & 8.35 & 8.54 & 8.25 & 9.21 & 8.31 & 10.80 & 11.94 & 11.79 & 2.10 \\
\hline $\mathrm{MnO}$ & 0.14 & 0.16 & 0.16 & 0.17 & 0.15 & 0.18 & 0.16 & 0.16 & 0.18 & 0.16 & 0.15 & 0.07 \\
\hline $\mathrm{MgO}$ & 6.12 & 6.43 & 6.37 & 8.26 & 8.17 & 6.89 & 4.62 & 6.94 & 2.83 & 3.95 & 7.10 & 0.25 \\
\hline $\mathrm{CaO}$ & 10.75 & 11.26 & 11.13 & 13.11 & 13.22 & 11.98 & 9.87 & 12.14 & 7.73 & 8.21 & 9.60 & 1.81 \\
\hline $\mathrm{Na}_{2} \mathrm{O}$ & 2.75 & 2.53 & 2.42 & 2.00 & 1.96 & 1.87 & 1.86 & 1.95 & 1.67 & 1.54 & 1.88 & 4.46 \\
\hline $\mathrm{K}_{2} \mathrm{O}$ & 0.11 & 0.12 & 0.19 & 0.05 & 0.06 & 0.28 & 0.33 & 0.28 & 0.42 & 0.44 & 0.64 & 1.44 \\
\hline Total & 98.10 & 98.33 & 98.78 & 98.53 & 97.99 & 98.82 & 98.29 & 98.50 & 96.96 & 97.38 & 98.19 & 100.01 \\
\hline
\end{tabular}

Notes: The asterisk $(*)$ represents shipboard data, recalculated to $100 \%$ anhydrous. Gmss $=$ groundmass. 